\title{
TERAPI AKUPRESUR DAPAT MENURUNKAN KELUHAN MUAL MUNTAH AKUT AKIBAT KEMOTERAPI PADA PASIEN KANKER: RANDOMIZED CLINICAL TRIAL
}

\author{
Hilman Syarif ${ }^{1,2^{*}}$, Elly Nurachmah ${ }^{3}$, Dewi Gayatri ${ }^{3}$ \\ 1. STIKES Cut Nyak Dhien Langsa, Nanggroe Aceh Darussalam 24415, Indonesia \\ 2. Program Studi Magister Fakultas Ilmu Keperawatan Universitas Indonesia, Depok 16424, Indonesia \\ 3. Fakultas Ilmu Kepearawtan Universitas Indonesia, Depok 16424, Indonesia \\ *Email:h11m4n@yahoo.com
}

\begin{abstract}
Abstrak
Akupresur merupakan salah satu terapi komplementer pada pasien yang mengalami mual muntah akut akibat kemoterapi. Tujuan riset ini untuk membuktikan pengaruh akupresur terhadap mual muntah akut pada pasien kanker di dua RS di Jakarta. Penelitian ini merupakan randomized clinical trial dengan metode single blind. Pengambilan sampel dengan cara consecutive sampling dan penentuan kelompok intervensi dan kontrol dengan randomisasi alokasi subjek sederhana. Sampel penelitian berjumlah 44 responden, terdiri dari 22 responden sebagai kelompok intervensi yang dilakukan terapi akupresur sebanyak tiga kali sehari, dan 22 responden sebagai kelompok kontrol. Pengujian perbedaan penurunan rerata skor mual, muntah, dan mual muntah pada kelompok intervensi dan kelompok kontrol menggunakan uji T test. Hasil penelitian menunjukkan penurunan rerata mual muntah akut setelah akupresur pada kelompok intervensi signifikan lebih besar dibanding dengan kelompok kontrol $(p=0,000 ; \alpha=0,05)$. Akupresur secara signifikan dapat menurunkan mual muntah akut akibat kemoterapi pada pasien kanker yang dilakukan akupresur dibandingkan dengan kelompok kontrol. Akupresur direkomendasikan dapat diterapkan sebagai bagian dari intervensi keperawatan dalam pemberian asuhan keperawatan pada pasien yang mengalami mual muntah akut akibat kemoterapi.
\end{abstract}

Kata kunci: akupresur, kemoterapi, mual muntah akut

\begin{abstract}
Acupressure is one of the complementary theraphies for patients with acute chemotherapy-induced nausea and vomiting (CINV). The objective of the study was to prove the effect of acupressure to acute CINV on patients with cancer at two hospitals in Jakarta. The research used randomized clinical trial with single blind method. A consecutive sampling was used as the sample collection method and simple randomization allocation subject was used to identify samples in the intervention or control group. The number of samples was 44 respondents, consisted of 22 subjects who were given an acupressure theraphy, three times a day; and the remaining was the control group. A t-test was used to examine the differences of the mean nausea and vomiting scores between the intervention and control groups. The result indicated that there is a signifant decrease of the mean acute nausea and vomiting scores after acupressure between the two groups $(p=0.000 ; \alpha=0.05)$. It was concluded that the acupressure can significantly decrease acute CINV on patients with cancer in the intervention group if compared with control group. Based on the findings, recommendation is directed to hospital management especially nursing management to apply acupressure as a nursing intervention to patients with acute CINV.
\end{abstract}

Keywords: acupressure, chemotherapy, acute nausea and vomiting

\section{Pendahuluan}

Kanker merupakan suatu ancaman serius terhadap kesehatan masyarakat, karena insiden dan angka kematiannya terus merayap naik. American Cancer Society (ACS) menyatakan sekitar 1.399.790 kasus baru kanker didiagnosis pada 2006 di Amerika (LeMone \& Burke, 2008). LeMone dan Burke juga mengungkapkan bahwa satu dari empat kematian disebabkan oleh kanker, dan lebih dari 1500 orang meninggal dikarenakan kanker setiap harinya. Di Indonesia, lebih kurang 6\% atau 13,2 juta jiwa penduduk Indonesia menderita penyakit kanker dan memerlukan pengobatan sejak dini. Angka tersebut hampir sama dengan beberapa negara berkembang lainnya. Berdasarkan data yang diperoleh dari Depkes RI, yang menyebutkan bahwa kanker merupakan penyebab kematian ke-5 di Indonesia, 
setelah penyakit jantung, stroke, penyakit saluran pernafasan, dan diare (Depkes RI, 2006).

Banyak terapi yang dilakukan terhadap kanker, diantaranya kemoterapi yang umumnya digunakan untuk terapi sistemik dan kanker dengan metastasis klinis ataupun subklinis. Pada kanker stadium lanjut secara lokal, kemoterapi sering menjadi satusatunya metode pilihan yang efektif. Hingga saat ini obat anti kanker jenis kemoterapi yang sudah dapat digunakan secara klinis mencapai 70 jenis lebih (Desen, 2008).

Obat-obat kemoterapi sering menimbulkan efek samping bagi pasien terutama mual muntah dengan derajat yang bervariasi. Obat golongan Sisplatin, Karmustin, dan Siklofospamid merupakan jenis obat yang mempunyai kemampuan tinggi dalam menimbulkan mual muntah. Lebih dari $90 \%$ pasien yang menggunakan obat golongan ini mengalami muntah (Hesketh, 2008).

Gejala mual muntah merupakan salah satu efek samping yang berat akibat pemberian obat kanker. Kondisi ini dapat menyebabkan stres terhadap pasien dan terkadang membuat pasien memilih untuk menghentikan siklus terapi dan berpotensi untuk menimbulkan harapan hidup yang buruk di masa depan. Disamping itu, jika efek samping ini tidak dapat ditangani dengan baik, maka mual muntah dapat menyebabkan terjadinya dehidrasi, ketidakseimbangan elektrolit, dan resiko terjadi aspirasi pneumonia (Hesketh, 2008; Ignatavicius \& Workman, 2008).

\section{Chemotherapy-induced nausea and vomiting} (CINV) dikategorikan dalam tiga jenis berdasarkan waktu terjadinya sehubungan dengan pemberian kemoterapi yaitu acute, delayed, dan anticipatory (Grunberg, 2004; Hesketh, 2008). Saat ini telah banyak terapi yang dikembangkan untuk mengatasi mual muntah dengan indeks terapi yang bervariasi. Meskipun telah diberikan terapi antiemetik, CINV khususnya yaitu mual, masih merupakan respon yang paling sering dijumpai pada pasien. Berdasar data dari Grunberg (2004) yang menunjukkan bahwa sekitar $60 \%$ pasien yang telah mendapatkan kemoterapi melaporkan bahwa pasien mengalami mual akut dan sekitar 30\% mengalami muntah akut meskipun sudah menggunakan antiemetik regimen terbaru.

Terapi komplementer yang dapat dilakukan dalam mengatasi mual muntah akibat kemoterapi yaitu salah satunya dengan akupresur. Stimulasi yang dilakukan pada titik $\mathrm{P}_{6}$ dan $\mathrm{St}_{36}$ diyakini akan memperbaiki aliran energi di lambung sehingga dapat mengurangi terjadi gangguan pada lambung termasuk mual muntah (Dibble, Luce, Cooper, \& Israel, 2007).

Pada hasil penelitian yang dilakukan oleh Tarcin, Gurbuz, Pocan, Keskin, dan Demirturk (2004), yang juga mengungkapkan informasi lain bahwa stimulasi pada titik $\mathrm{P}_{6}$ mempunyai manfaat dalam peningkatan pengeluaran beta endorpin di hipofisis di sekitar CTZ. Beta endorpin merupakan salah satu antiemetik endogen yang dapat menghambat impuls mual muntah di pusat muntah dan CTZ (Samad, Afshan, \& Kamal, 2003).

Akupresur sebagai salah satu terapi komplementer dalam mengatasi mual muntah telah dibuktikan oleh beberapa penelitian, salah satu diantaranya adalah penelitian Dibble, et al. (2007). Penelitian tersebut bertujuan membandingkan perbedaan mual muntah akibat kemoterapi pada 160 orang wanita. Responden dibagi ke dalam tiga kelompok, terdiri dari; kelompok yang mendapat akupresur, placebo akupresur, dan mendapat perawatan yang biasa.

Hasil penelitian Dibble, et al. yang menunjukkan bahwa terdapat perbedaan pada intensitas mual dan muntah yang bermakna pada kelompok yang mendapat akupresur bila dibandingkan dengan kelompok plasebo dan kelompok yang mendapat perawatan yang biasa. Selain itu, dalam penelitian tersebut didapatkan bahwa tidak ada perbedaan yang bermakna pada kelompok plasebo akupresur dan kelompok yang mendapatkan perawatan yang biasa. 
Peneliti mengamati bahwa akupresur belum pernah diaplikasikan sebagai intervensi keperawatan yang digunakan untuk mengatasi maupun mencegah mual muntah akibat dari pemberian kemoterapi, khususnya di dua rumah sakit di wilayah Jakarta yang dijadikan lokasi/tempat penelitian. Penelitian ini bertujuan untuk mengidentifikasi pengaruh dari akupresur terhadap mual muntah akut akibat dari kemoterapi pada pasien kanker di dua rumah sakit di wilayah Jakarta.

Tabel 1. Distribusi Responden Berdasarkan Usia

\begin{tabular}{rccccc}
\hline Variabel & Mean & SD & N & Min-mak & OR 95\% CI \\
\hline Usia & 43,75 & 10,76 & 44 & $19-61$ & $40,48-47,02$ \\
\hline
\end{tabular}

\section{Metode}

Desain penelitian ini adalah randomized clinical trial dengan metode single blind. Kriteria inklusi yang meliputi; pasien dengan usia di atas 18 tahun, kooperatif, dalam kondisi sadar, dapat berorientasi pada tempat, waktu, dan orang, dapat membaca dan menulis, serta cara pemberian kemoterapi melalui intravena. Sedangkan kriteria eksklusi yaitu terdiri dari; pasien yang mengalami anticipatory, nausea, dan vomiting, pasien dengan riwayat penggunaan alkohol, riwayat mual muntah akibat perjalanan atau kehamilan, penderita kanker saluran cerna, kanker hati, dan kanker pankreas, pasien yang memiliki kontraindikasi akupresur, serta pasein dalam siklus kelima atau lebih.

Sampel diambil secara concecutive sampling dan randomisasi alokasi subjek diaplikasikan untuk menentukan kelompok intervensi dan kontrol. Dari 44 total sampel, 22 pada kelompok intervensi dan 22 pada kelompok kontrol. Kelompok intervensi mendapatkan terapi antiemetik standar dan dilakukan akupresur 3 kali sehari, 25 menit sebelum kemoterapi serta 6 dan 12 jam setelah kemoterapi. Sementara kelompok kontrol hanya mendapatkan terapi standar.

Pengukuran mual muntah didapatkan berdasarkan penjumlahan hasil isian pasien dan keluarga pada kuesioner mual muntah setiap 12 jam setelah mendapatkan kemoterapi dan dilakukan pada dua siklus pemberian kemoterapi yang berurutan. Data pre-test didapat pada satu siklus, dimana kelompok intervensi dan kontrol tidak dilakukan intervensi. Data post-test didapat pada siklus berikutnya, dimana kelompok intervensi dilakukan terapi akupresur, sementara kelompok kontrol tidak dilakukan terapi akupresur.

Alat pengumpul data yang digunakan terdiri dari dua kuesioner, yaitu kuesioner data demografi dan kuesioner mual muntah. Kuesioner data demograpi digunakan untuk mengukur data usia responden, jenis kelamin, diagnosis medis, siklus kemoterapi, obat kemoterapi yang digunakan, obat antiemetik yang digunakan, dan sistem pemberian kemoterapi. Kuesioner mual muntah digunakan dengan tujuan untuk mengukur mual muntah yang dimodifikasi dari Rhodes Index Nausea, Vomiting, and Retching . Pengisian kuesioner tersebut yaitu dibantu dengan menggunakan gelas ukur, sedangkan kuesioner penilaian distres yang telah dimodifikasi dari StateTrait Anxiety Inventory yang dipopulerkan oleh Spielberg.

Uji validitas dan reliabilitas pada penelitian ini dilakukan sebelum penggunaan kuesioner terhadap 30 pasien yang karakteristik pasien sama dengan responden penelitian. Berdasarkan pada hasil uji validitas menggunakan Pearson dan uji reliabilitas menggunakan Alpha-Cronbach didapatkan bahwa semua item pertanyaan valid ( $r>0,349)$. Pada uji reliabilitas terhadap semua poin didapatkan bahwa semua pertanyaan reliabel, dengan nilai $r$ Alpha 0,911 lebih besar dibandingkan dengan t tabel. Analisis bivariat menggunakan $t$ pooled test dan $t$ paired test. 


\section{Hasil}

\section{Karakteristik Responden}

Tabel 1 menunjukkan usia responden penelitian ini paling rendah 19 tahun dan maksimum berusia 61 tahun. Rerata usia responden adalah 43,75 tahun $(\mathrm{SD}=10,76)$. Berdasarkan estimasi diyakini bahwa rerata usia responden penelitian berada diantara 40,48 sampai dengan 47,02 tahun.

Pada tabel 2 menunjukkan bahwa sebagian besar $(63,6 \%)$ responden berjenis kelamin perempuan, begitupun pada kelompok kontrol $(68,2 \%)$ maupun kelompok intervensi $(59,1 \%)$. Sisanya berjenis kelamin laki-laki yaitu sebanyak 36,4\%. Sebagian besar responden $(65,9 \%)$ menggunakan kemoterapi dengan derajat emetogenik tinggi. Sisanya sebesar $34,1 \%$ responden yang menggunakan kemoterapi dengan derajat emetogenik yang sedang. Seluruh responden menggunakan terapi antiemetik dengan indeks terapi tinggi, baik pada kelompok kontrol dan kelompok intervensi. Tidak terdapat responden yang menggunakan antiemetik indeks terapi yang rendah, baik terhadap kelompok kontrol maupun kelompok intervensi.

Sebagian besar responden (54,5\%) menggunakan kemoterapi dengan sistem pemberian singleday. Sisanya sebesar $45,5 \%$ responden menggunakan kemoterapi dengan metode pemberian multiday. Berdasarkan siklus kemoterapi responden hampir merata untuk masing-masing siklus. Paling banyak responden berada pada siklus ketiga yaitu 14 orang $(31,8 \%)$, sedangkan untuk siklus pertama, kedua, dan keempat masing-masing 18,2\%, 29,5\%, dan $20,25 \%$.

Tabel 2. Distribusi Responden berdasarkan Jenis Kelamin, Kemoterapi, Antiemetik, Sistem Pemberian Kemoterapi, dan Siklus Kemoterapi

\begin{tabular}{lc}
\hline Variabel & Total $(\boldsymbol{\%})$ \\
\hline Jenis Kelamin & $16(36,4)$ \\
Laki-laki & $28(63,6)$ \\
Perempuan & \\
Kemoterapi & $15(34,1)$ \\
Emetogenik Sedang & $29(65,9)$ \\
Emetogenik Tinggi & \\
Antiemetik & \\
Indeks tinggi & $44(100)$ \\
Metode Pemberian & \\
Singleday & $24(54,5)$ \\
Multiday & $20(45,5)$ \\
Siklus Kemoterapi & \\
1 & \\
2 & \\
3 & $8(18,2)$ \\
4 & $13(29,5)$ \\
\hline
\end{tabular}




\section{Perbandingan Rerata Skor Mual, Muntah, dan Mual Muntah Setelah Akupresur pada Kelompok Intervensi dan Kontrol}

Hasil rerata mual setelah dilakukan akupresur pada kelompok intervensi yaitu 3,55 (0-24) $(\mathrm{SD}=1,471)$, sedang kelompok yang tidak dilakukan akupresur mualnya adalah 5,68 $(\mathrm{SD}=2,009)$. Analisis lebih lanjut menunjukkan bahwa adanya perbedaan yang bermakna rerata mual terhadap kelompok yang dilakukan akupresur dengan yang tidak dilakukan $(p=0,000 ; \alpha=0,05)$.

Akupresur yang telah dilakukan pada kelompok intervensi menunjukkan bahwa rerata muntah yaitu 2,09 (0-24) ( $\mathrm{SD}=1,716)$. Pada kelompok kontrol, rerata muntahnya adalah 4,05 $(\mathrm{SD}=1,889)$. Hasil analisis menunjukkan bahwa terdapat perbedaan yang bermakna rerata muntah pada kelompok yang dilakukan akupresur dengan yang tidak dilakukan $(p=0,001 ; \alpha=0,05)$.

Rerata mual muntah setelah dilakukan akupresur pada kelompok intervensi adalah 5,64 (0-48) $(\mathrm{SD}=$ 2,700), sedangkan kelompok yang tidak dilakukan akupresur mual muntahnya adalah 9,89 ( $\mathrm{SD}=$ 3,418). Analisis selanjutnya menunjukkan bahwa perbedaan yang bermakna rerata mual muntah pada kelompok intervensi dengan kelompok $\operatorname{kontrol}(\mathrm{p}=$ $0,000 ; \alpha=0,05)$.

\section{Pembahasan}

Rerata skor mual muntah setelah akupresur berbeda secara bermakna antara kelompok yang dilakukan akupresur dengan kelompok yang tidak dilakukan akupresur $(\mathrm{p}=0,000 ; \alpha=0,05)$. Hasil penelitian ini telah menunjukkan akupresur yang dilakukan pada responden yang mendapatkan kemoterapi atau kelompok intervensi dapat menurunkan skor mual muntah akut sebesar 3,72. Hal yang sebaliknya terjadi pada kelompok kontrol, yaitu peningkatan skor mual muntah sebesar 0,27.

Hasil penelitian menggambarkan bahwa akupresur yang dilakukan menurunkan skor mual muntah akut secara bermakna terhadap responden yang mengalami mual muntah akut akibat kemoterapi. Dengan demikian, akupresur merupakan intervensi yang efektif dalam rangka menurunkan mual pada pasien kanker yang mendapat kemoterapi. Temuan ini sesuai dengan temuan Dibble, et al. (2007) yang mengatakan bahwa akupresur merupakan salah satu tindakan yang tepat dalam manajemen mual muntah akibat kemoterapi.

Akupresur yang dilakukan pada responden yang mendapatkan kemoterapi atau kelompok intervensi dapat menurunkan skor mual muntah akut sebesar 3,72. Penelitian lain yang mendukung temuan ini telah dilakukan oleh Molassiotis, Helin, Dabbour, dan Hummerston (2007) di Inggris. Penelitian tersebut membandingkan mual dan muntah pada 36 responden wanita yang mendapat kemoterapi karena kanker payudara. Responden dibagi ke dalam dua kelompok yaitu kelompok eksperimen yang mendapatkan akupresur pada titik $\mathrm{P}_{6}$ dan kelompok kontrol yang tidak dilakukan akupresur.

Hasil penelitian yang dilakukan Molassiotis, et al. menunjukkan bahwa terdapat angka pengalaman mual dan muntah yang bermakna lebih rendah pada kelompok eksperimen dibanding dengan kelompok kontrol. Hasil rerata pengalaman mual muntah pada kelompok intervensi yaitu sebesar 1,53 dan pada kelompok kontrol sebesar 3,66 $(p=0,001 ; \alpha=0,05)$.

Akupresur menurut pandangan peneliti dapat menurunkan mual muntah akut akibat kemoterapi pada pasien kanker secara umum dengan melalui manipulasi yaitu pada titik akupresur tersebut. Manipulasi pada titik akupresur $\mathrm{P}_{6}$ dan $\mathrm{St}_{36}$ dapat memberikan manfaat berupa perbaikan energi yang ada di meridian limpa dan lambung, sehingga memperkuat sel-sel saluran pencernaan terhadap efek kemoterapi yang dapat menurunkan rangsang mual muntah ke pusat muntah. Manipulasi tersebut juga dapat merangsang peningkatan beta endopin di hipofise yang dapat menjadi antiemetik alami melalui kerjanya menurunkan impuls mual muntah di chemoreseptor trigger zone (CTZ) dan pusat muntah (Tarcin, et al., 2004). 
Penelitian lain yang mendukung hasil penelitian ini adalah penelitian yang dilakukan oleh Dibble, et al. (2007). Pada penelitiannya Dibble, et al. membandingkan perbedaan mual muntah akibat dari kemoterapi pada 160 orang wanita. Responden penelitian tersebut dibagi ke dalam tiga kelompok yang terdiri dari; kelompok yang mendapatkan akupresur, mendapatkan plasebo akupresur, dan mendapatkan perawatan yang biasa.

Hasil penelitian ini menunjukkan bahwa terdapat perbedaan pada intensitas mual dan muntah yang bermakna pada kelompok yang mendapatkan akupresur bila dibandingkan dengan kelompok plasebo dan kelompok yang mendapat perawatan yang biasa. Selain itu, tidak ada perbedaan yang bermakna pada kelompok plasebo akupresur dan kelompok yang mendapat perawatan yang biasa.

Penelitian yang dapat dijadikan sebagai pendukung penelitian ini juga pernah dilakukan oleh Dibble, Chapman, Mack, dan Shih (2000). Penelitian mereka bertujuan membandingkan perbedaan dari mual muntah diantara pasien yang mendapatkan antiemetik allopatik dengan pasien yang mendapat antiemetik allopatik ditambah dengan akupresur. Penelitian tersebut dilakukan pada 17 orang wanita dengan rawat jalan yang mendapat kemoterapi di klinik onkologi, delapan orang diantaranya yaitu sebagai kelompok yang mendapat terapi akupresur selama maksimal tiga menit setiap pagi dan sesuai kebutuhan untuk menyembuhkan gejala.

Tabel 3. Perbandingan Rerata Skor Mual, Muntah, dan Mual Muntah Setelah Akupresur pada Kelompok Intervensi dan Kontrol

\begin{tabular}{lcccc}
\hline Variabel & Kelompok & Mean & SD & p \\
\hline Skor Mual & Intervensi & 3,55 & 1,471 & $0,000^{*}$ \\
& Kontrol & 5,68 & 2,009 & $0,001^{*}$ \\
Skor Muntah & Intervensi & 2,09 & 1,716 & 1,889 \\
& Kontrol & 4,05 & & $0,000^{*}$ \\
& & & 2,700 & \\
Skor Mual Muntah & Intervensi & 5,64 & 3,418 & \\
& Kontrol & 9,59 & & \\
\hline
\end{tabular}

*Bermakna pada $\alpha=0,05$

Hasil penelitian menunjukkan skor pengalaman mual akut pada kelompok intervensi adalah 1,8 dan pada kelompok kontrol adalah 5,0. Penelitian menghasilkan kesimpulan bahwa ada perbedaan yang bermakna secara statistik dalam pengalaman mual serta intensitas mual muntah bila dibanding dengan kelompok kontrol.
Temuan pada penelitian ini juga tidak jauh berbeda dengan temuan penelitian yang dilakukan Roscoe, et al. (2003). Penelitian dengan desain RCT tersebut dilakukan pada 739 responden yang mendapatkan kemoterapi dikarenakan kanker. Responden dibagi kedalam tiga kelompok yaitu kelompok akupresur, kelompok akustimulasi, dan kelompok plasebo. 
Hasil akhir penelitian Roscoe, et al. menunjukkan bahwa responden yang dilakukan akupresur pada titik $\mathrm{P}_{6}$ mengalami penurunan muntah akut yang bermakna dibandingkan kelompok akustimulasi dan kelompok plasebo $(\mathrm{p}<0,005)$.

Pendapat tersebut didukung dengan hasil penelitian yang dilakukan oleh Dibble, et al. (2007), yang mengatakan bahwa penurunan mual muntah terjadi karena stimulasi berupa penekanan pada titik $\mathrm{P}_{6}$ dan $\mathrm{St}_{36}$ memberikan efek terapi di tubuh. Stimulasi yang dilakukan dapat memperbaiki aliran energi di lambung sehingga dapat mengurangi gangguan pada lambung termasuk mual muntah.

Pendapat lain juga dikemukakan oleh Tarcin, et al. (2004) dan Samad, et al. (2003) yang menunjukkan bahwa stimulasi pada titik $\mathrm{P}_{6}$ dapat meningkatkan pengeluaran beta endorpin di hipofisis di sekitar CTZ, dimana beta endorpin yang merupakan salah satu antiemetik endogen yang dapat menghambat impuls mual muntah di pusat muntah dan CTZ. Berdasarkan penemuan tersebut, diharapkan agar akupresur dapat diaplikasikan untuk membantu pasien dalam rangka menurunkan mual muntah akibat kemoterapi.

Dalam penelitian ini kondisi demografi didapatkan bahwa tidak mempengaruhi hasil penelitian. Uji homogenitas dilakukan sebelum pengolahan data mual muntah. Pada uji homogenitas menunjukkan bahwa tidak terdapat perbedaan bermakna pada karakteristik responden pada kelompok intervensi dan kelompok kontrol. Sedang, usia, jenis kelamin, derajat emetogenik kemoterapi, antiemetik, siklus kemoterapi, serta metode pemberian kemoterapi berada dalam kondisi homogen antara kelompok interevensi dan kelompok kontrol.

\section{Kesimpulan}

Hasil penelitian yang diperoleh dapat disimpulkan bahwa karakteristik dari 44 responden, meliputi; rata-rata usia 43,75 tahun, sebagian besar $(63,6 \%)$ yaitu berjenis kelamin perempuan, sebagian besar $(65,9 \%)$ menggunakan kemoterapi dengan derajat emetogenik yang tinggi, semua responden (100\%) menggunakan antiemetik dengan indeks terapi tinggi, sebagian besar diberikan kemoterapi dengan metode single day dan sebagian besar $(31,8 \%)$ pada siklus ketiga. Penurunan rerata skor mual, muntah, serta mual muntah setelah dilakukan akupresur pada kelompok intervensi lebih besar dibandingkan dengan pada kelompok kontrol $(\mathrm{p}<0,005)$.

Kesimpulannya, secara bermakna akupresur dapat menurunkan mual muntah akut akibat kemoterapi pada pasien kanker yang dilakukan akupresur dibanding dengan kelompok kontrol. Berdasarkan temuan pada penelitian ini, maka rekomendasi dari penelitian adalah agar akupresur dapat diterapkan sebagai bagian dari intervensi keperawatan dalam pemberian asuhan keperawatan pada pasien yang mengalami mual muntah akut akibat kemoterapi (US, RS, TN).

\section{Referensi}

Collin, K.B., \& Thomas, D.J. (2004). Accupuncture and accupressure for the Management of Chemotherapy-Induced Nausea and Vomiting. Journal of the American Academy of Nurse Practitioner, 16 (2), 76-80.

Depkes RI. (2006). Enam persen penduduk RI menderita kanker. Diperoleh dari http://www. depkes.go.id/.

Desen, W. (2008). Buku ajar onkologi medik. Edisi 2. Jakarta: Balai Penerbit Fakultas Kedokteran Universitas Indonesia.

Dibble, S.L., Chapman, J., Mack, K.I., \& Shih, A. (2000). Acupressure for nausea. Diperoleh dari http://web.ebscohost.com/.

Dibble, S.L., Luce, J., Cooper, B.A., \& Israel, J. (2007). Acupressure for chemoterapy-induced nausea \& vomiting: A randomized clinical trial. Oncology Nursing Forum, 34 (4), 813-820.

Grunberg, S.M. (2004). Chemotherapy-induced nausea and vomiting: Prevention, detection, \& treatment-how are we doing? The Journal of Supportive Oncology, 2 (1), 1-12. 
Hesketh, P.J. (2008). Chemotherapy-induced nausea \& vomiting. The New England Journal of Medicine, 358 (23), 2482-2494. DOI: 10.1056/ NEJMra0706547.

Ignatavicius, D.D., \& Workman. M.L. (2006). Medical surgical nursing: Critical thinking for collaborative care (5th Ed.). Philadelphia: W.B. Saunders Company.

LeMone, P., \& Burke, K. (2008). Medical surgical nursing: Critical thinking in client care (4th Ed.). New Jersey: Pearson Prentice Hall.

Molassiotis, A., Helin, A.M., Dabbour, R., \& Hummerston, S. (2007). The effects of P6 accupressure in the profilaxis of chemotherapy related nausea and vomiting in breast cancer patients. Complementary Therapies in Medicine, 15 (1), 3-12.
Roscoe, J.A., Morrow, G.R., Hickok, J.T., Bushunow, P., Pierce, H.I., Flynn, P.J., et al. (2003). The efficacy of accupressure and accustimulation wrist bands for the relief of chemotherapy-induced nausea and vomiting. Journal of Pain and Symptom Management, 26 (2), 731-742.

Samad, K., Afshan, G., \& Kamal, R. (2003). Effect of acupressure on postoperative nausea and vomiting in laparoscopic cholecystectomy. J Pak Med Assoc, $53(2), 68-72$.

Sukanta, P. O. (2008). Terapi pijat tangan. Jakarta: Penebar Plus.

Tarcin, O., Gurbuz, A.K., Pocan, S., Keskin, O., \& Demirturk, L. (2004). Accustimulation of the Neiguan point during gastroscopy: Its effect on nausea and retching. The Turkish Journal of Gastroenterology, 15 (4), 258-262. 